\title{
The effect of Cassia alata L. leaf extract on egg hatching and survival of Pangasianodon hypophthalmus larvae
}

\author{
Iko Imelda Arisa ${ }^{1,3,4^{*}}$, Sri Agustina ${ }^{2,3,5}$, and Lisa Handayani $^{1}$ \\ ${ }^{1}$ Departement of Aquaculture, Marine and Fisheries Faculty, Universitas Syiah Kuala, Banda Aceh, Aceh, 23111 Indonesia \\ ${ }^{2}$ Departement of Marine Science, Marine and Fisheries Faculty, Universitas Syiah Kuala, Banda Aceh, Aceh, 23111Indonesia \\ ${ }^{3}$ Research Center for Marine and Fisheries, Universitas Syiah Kuala, Banda Aceh, Aceh, 23111 Indonesia \\ ${ }^{4}$ Animal Histology and Fish Nutrition Laboratory, Marine and Fisheries Faculty, Universitas Syiah Kuala, Banda Aceh, Aceh, 23111 \\ Indonesia \\ ${ }^{5}$ Laboratory of Marine Chemistry and Biotechnology of Fisheries, Marine and Fisheries Faculty, Universitas Syiah Kuala, Banda \\ Aceh, Aceh, 23111 Indonesia
}

\begin{abstract}
This study aims to determine the effect of using Cassia alata L. leaf extract on the prevention of fungus on fish eggs Pangasianodon hypophthalmus This research was conducted at the Blangpidie Fish Seed Center. Aceh Barat Daya from July to August 2020. Statistical analysis used a completely randomized design (CRD) method with 7 treatment levels and 3 replications. The treatments were conducted by soaking the fish eggs in the leaf extract for 20 minutes. Those treatments were A (control), B (2.5 ppm), C (5 ppm), $\mathrm{D}(7.5 \mathrm{ppm}) \mathrm{E}(10 \mathrm{ppm}), \mathrm{F}(12.5 \mathrm{ppm})$, and $\mathrm{G}(15 \mathrm{ppm})$. ANOVA test results showed that the addition of leaf extract $C$. alata had a significant $(\mathrm{P}<0.05)$ effect on hatchability and survival of $P$. hypophthalmus larvae. A concentration of $15 \mathrm{ppm}$ is the best with a hatchability value of $85.33 \%$ and a concentration of 10 ppm is the most optimum for the survival value of $P$. hypophthalmus larvae, namely $92.99 \%$.
\end{abstract}

\section{Introduction}

Pangasianodon hypophthalmus is one of the potential aquaculture commodities to be developed. However, according to Muhlis et al. [1], P. hypophthalmus hatchery activities encountered several obstacles, including disease attacks in the egg phase caused by fungi. Fungal infection at the time of hatching eggs affects the damage to the eggs and causes a decrease in hatchability. Furthermore Larasati et al. [2] also mentions that the problem that is often faced in catfish farming is the low degree of egg hatching. Low egg hatchability will have an impact on the supply of catfish seeds which are low, so that aquaculture production activities are also low.

Efforts to control disease in cultured fish eggs due to pathogenic infections that use chemicals or antibiotics in the long term can have negative impacts, among others, can cause bacterial and fungal resistance and can pollute the environment $[3,4]$. So the disease requires alternative treatments such as the use of natural ingredients. One of the natural ingredients that has the potential to inhibit the growth of pathogens in fish is the use of Cassia alata leaves. This plant is known by different names in different countries, namely as Gelenggang (Malaysia), Ketepeng Badak or Ketepeng Cina (Indonesia) and bush ringworm (Australia) and has been used as as traditional medicine to treat various diseases $[5,6]$.

\section{Material and methods}

The research was carried out in July to August 2020 at the Blang Pidie Fish Seeds Center, Aceh Barat Daya District, Aceh Indonesia. The research design used was a completely randomized design (CRD) consisting 7 treatments and 3 replications. As for the types of treatments tested were as follows: $\mathrm{A}=$ immersion without $C$. alata leaves extract $(0 \mathrm{ppm}) ; \mathrm{B}=$ immersion with C.alata leaves extract at a dose of $2.5 \mathrm{ppm}$; $\mathrm{C}=$ immersion with C.alata leaves extract at a dose of 5 ppm; $\mathrm{D}=$ immersion with C.alata leaves extract dose of $7.5 \mathrm{ppm}$; $\mathrm{E}=$ immersion with $C$. alata leaves extract at a dose of $10 \mathrm{ppm} ; \mathrm{F}=$ immersion with $C$.alata leaves extract at a dose of $12.5 \mathrm{ppm} ; \mathrm{G}=$ immersion with $C$. alata leaves extract at a dose of $15 \mathrm{ppm}$.

\subsection{Cassia alata L. leaves extract}

Cassia alata leaves were washed with clean water and dried under the sun light until the leaves were easily crushed. The dried leaves are ground into flour. A total of $\pm 500 \mathrm{~g}$ of $C$. alata leaves powder was soaked in $3 \mathrm{~L}$ $96 \%$ PA absolute ethanol for 24 hours. The results of the immersion are filtered (Whattman No.41), the results are extracted using a rotary evaporator, then the extract is stored at $-5{ }^{\circ} \mathrm{C}$ until it is used for testing.

\footnotetext{
*Corresponding author: ikoimeldaarisa@unsyiah.ac.id
} 


\subsection{Fish eggs soak}

Fish eggs Pangasianodon hypophthalmus 50 healthy eggs that have been fertilized are put into each treatment container. Futhermore, as many as 25 fish eggs that have been infected with fungi and put into each of these containers and then left for 6 hours. After the healthy eggs were infected with the fungus, they were transferred to each container which was given a solution of $C$. alata leaf extract in accordance with the provisions of the treatment concentration. The eggs were soaked in a solution of $C$. alata leaf extract for 20 minutes.

\subsection{Observed parameters}

\subsubsection{Eggs condition}

Observation of eggs started after soaking using C. alata leaf extract until the eggs hatched. Eggs infected with fungi will show clinical symptoms in the form of threads like cotton covering the eggs. Observations of eggs that recovered due to fungal infection after soaking were observed every 1 hour interval using a microscope.

\subsubsection{Hatching rate (HR)}

Calculation of egg hatching rate parameter in research based on Arfiah et al. [9]:

$$
H R=\frac{\text { Number of eggs that hatch }}{\text { Number of fertilized eggs }} \times 100 \%
$$

Where: HR = Hatching Rate $(\%)$

\subsubsection{Survival rate}

Calculation of survival rate parameter in research based on Effendie [10]:

$$
S R=\frac{N o-N t}{N o} \times 100
$$

Where: $\mathrm{SR}=$ Survival Rate $(\%)$; $\mathrm{Nt}=$ number of test dead fish that died during rearing (ind); No =the total number of test fish observed (ind).

\subsubsection{Water quality parameters}

Several water quality parameters measured during the study were $\mathrm{pH}$, temperature, and dissolved oxygen. $\mathrm{pH}$ parameter measurement using a $\mathrm{pH}$ meter (PCSTestr ${ }^{\mathrm{TM}}$ $35)$, temperature parameter measurement was carried out using a thermometer (PCSTestr ${ }^{\mathrm{TM}} 35$ ) and dissolved oxygen parameter measurement using a DO meter (Thermo Scientific Eutech DO $6^{+}$). Water quality parameters measurements are carried out every day.

\subsection{Data analysis}

Research parameter data such as egg hatchability and survival rate of fish were analyzed using Analysis of Variance (ANOVA), if the results were influential then Duncan's test was performed with a $95 \%$ confidence level. While the water quality parameter measurement data is presented descriptively.

\section{Results and Discussion}

Cassia alata extract has enormous pharmacological value in supporting the use of traditional medicine in curing several important diseases, including antioxidant, anti-fungal and anti-bacterial properties [11]. Based on the results of the study, it was found that the use of $C$. alata leaf extract could increase egg hatchability and survival of $P$. hypophthalmus (Table 1), where the higher the dose of extract used in the treatment will also increase the hatchability of fish eggs. Fatmawati et al. [6] stated that C. alata leaf extract contains chemical compounds that can be used as antimicrobials. Furthermore, Makinde et al [12] said that the antibacterial and antifungal activity of the aqueous and methanolic extracts of $C$. alata leaves found that they had more antifungal properties than antibacterial. Phytochemical analysis of $C$. alata extract including flavonoids, tannins, steroids, phenols and alkaloids [13, 14, 15]. Then Roshida et al. [16] stated that tannins are antibacterial by presipitating protein. The antimicrobial effect of tannins through reactions with cell membrane inctivation of enzymes, destruction or inactivation of functions. Meanwhile, flavonoids have antimicrobial properties can form complex compounds with dissolved extracellular proteins and microbial cell walls. Falvonoids also have antibacterial and antioxidant properties that work by increasing the immune system, where leukocytes as antigen-eaters are produced faster and activate the lymphoid system more quickly [17-19].

The data from this study showed that the highest hatchability of fish eggs was found in the $15 \mathrm{ppm}$ treatment, which was $85.33 \%$. This indicates that the antifungal content of Cassia alata leaf extract with a concentration of $15 \mathrm{ppm}$ is optimal in inhibiting the fungus Saprolegnia sp. to infect P. Hypophthalmus fish eggs. C. alata is a traditional medicine that has excellent antibacterial and antifungal properties [20-21]. Previous research Bowo et al. [22] stated that a concentration of $60 \mathrm{ppm} \mathrm{C.} \mathrm{alata}$ leaf extract showed the best results in inhibiting the growth of the fungus Saprolegnia sp, while for egg hatchability and survival of gouramy larvae the highest was obtained at a concentration of 10 ppm.

Tabel 1. Hatching rate and survival rate of $P$. hypophthalmus

\begin{tabular}{|l|c|c|}
\hline \multirow{2}{*}{ Treatments } & \multicolumn{2}{|c|}{ Parameters } \\
\cline { 2 - 3 } & $\begin{array}{c}\text { Hatching Rate } \\
(\%)\end{array}$ & $\begin{array}{c}\text { Survival Rate } \\
(\%)\end{array}$ \\
\hline A $(0 \mathrm{ppm})$ & $22.00 \pm 4.0^{\mathrm{a}}$ & $55.32 \pm 16.4^{\mathrm{a}}$ \\
\hline $\mathrm{B}(2.5 \mathrm{ppm})$ & $37.33 \pm 6.1^{\mathrm{b}}$ & $74.45 \pm 12.3^{\mathrm{ab}}$ \\
\hline $\mathrm{C}(5 \mathrm{ppm})$ & $45.33 \pm 5.0^{\mathrm{b}}$ & $81.75 \pm 10.7^{\mathrm{ab}}$ \\
\hline $\mathrm{D}(7.5 \mathrm{ppm})$ & $61.33 \pm 7.6^{\mathrm{c}}$ & $90.56 \pm 9.4^{\mathrm{b}}$ \\
\hline E (10 ppm) & $67.33 \pm 8.1^{\mathrm{cd}}$ & $92.99 \pm 8.7^{\mathrm{b}}$ \\
\hline F (12.5 ppm) & $75.33 \pm 3.0^{\mathrm{de}}$ & $90.29 \pm 3.9^{\mathrm{b}}$ \\
\hline G (15 ppm) & $85.33 \pm 5.0^{\mathrm{e}}$ & $92.73 \pm 1.3^{\mathrm{b}}$ \\
\hline
\end{tabular}

Note:writing different superscripts in the column indicates a significant difference between treatments $(\mathrm{P}<0,05)$. 
Tabel 2 Water quality parameters measurement data

\begin{tabular}{|l|c|c|c|}
\hline \multicolumn{1}{|c|}{ Treatments } & $\begin{array}{c}\text { Temperature } \\
\left({ }^{\circ} \mathrm{C}\right)\end{array}$ & $\mathrm{pH}$ & $\begin{array}{c}\mathrm{DO} \\
\left(\mathrm{mgL}^{-1}\right)\end{array}$ \\
\hline $\mathrm{A}(0 \mathrm{ppm})$ & $26.4-26.8$ & $6,7-6.5$ & $5.3-5.5$ \\
\hline $\mathrm{B}(2.5 \mathrm{ppm})$ & $26.5-26.9$ & 6.6 & $5.4-5.6$ \\
\hline $\mathrm{C}(5 \mathrm{ppm})$ & $26.5-26.9$ & $6.5-6.7$ & $5.4-5.5$ \\
\hline $\mathrm{D}(7.5 \mathrm{ppm})$ & $26.6-26.8$ & $6.5-6.7$ & $5.4-5.5$ \\
\hline $\mathrm{E}(10 \mathrm{ppm})$ & $26.6-26.9$ & $6.6-6.7$ & $5.4-5.5$ \\
\hline $\mathrm{F}(12.5 \mathrm{ppm})$ & $26.6-26.9$ & $6.5-6.7$ & $5.4-5.6$ \\
\hline $\mathrm{G}(15 \mathrm{ppm})$ & $26.5-26.9$ & $6.5-6.7$ & $5.4-5.5$ \\
\hline
\end{tabular}

The results of the analysis of variance in use of $C$. alata leaf extract had an effect on survival of catfish larvae $(\mathrm{P}<0.05)$. During the study, the observation of the survival rate of $P$. hypophthalmus larvae was categorized as good. It is suspected that the chemical content in leaf extractof C. alata was able to inhibit the growth of fungi in P. hypophthalmus eggs.

Good water quality management can inhibit the spread of fungi in hatchery activities both at time of hatching eggs and rearing post larvae in aquaculture activities. Good management of aquaculture media water quality will suppress the spread of fungal diseases through water management is carried out for all water quality parameters, both chemical, physical and biological. During the research, it was found that the water quality parameters measurement value data still within the tolerance range of $P$. hypophthalmus (Table 2). Based on the Indonesian National Standard [23], the optimal $\mathrm{pH}$ value for catfish rearing ranges from 6.5 8.5. The value of dissolved oxygen in the media for hatching eggs and rearing $P$. hypophthalmus larvae is $>$ $5 \mathrm{mgL}-1$. Furthermore, the research of Putra et al. [24] states that the water quality for hatching and rearing catfish larvae is a temperature of $26.2-27.90$ and dissolved oxygen $4.7-5.5 \mathrm{mgL}^{-1}$.

\section{Conclusion}

The use of Cassia alata L. leaf extract make an impact to hatchability of fish eggs and the survival of Pangasianodon hypophthalmus fish larvae. The highest fish egg hatchability value of $85.33 \%$ was obtained by soaking $C$. alata leaf extract at a dose of $15 \mathrm{ppm}$ and the survival value the highest fish larvae of $92.99 \%$ was obtained at a dose of $10 \mathrm{ppm}$.

\section{Reference}

1. Muhlis, M. Ghofur, M. Sugihartono, J Akuakultur Sungai dan Danau 4, 1 (2019)

2. S. Larasati, F. Basuki, T. Yuniarti, J of Aquaculture Management and Technology 6, 4 (2017)

3. Noga, Pestisida Nabati untuk Penyakit Ikan (Penebar Swadaya, Jakarta, 2010)

4. D.Q. Pham, H.T. Pham, J.W. Han, T.H. Nguyen, H.T. Nguyen, T.D. Nguyen, T.T.T. Nguyen, C.T. Ho, H.M. Pham, H.D. Vu, G.J. Choi, Q.L. Dang, Industrial Crops \& Products 166 (2021)
5. Y.Y. Ling, P.S. Fun, A. Yeop, M.M. Yusoff, J. Gimbun, Material Todays: Proceedings 19 (2019)

6. S. Fatmawati, Yuliana, A.S. Purnomo, M.F.A. Bakar, Helion 6 (2020)

7. M. Bahi., R. Mutia., E. Mustanir, Lukitaningsih, $J$ Natural 14, 1 (2014)

8. S. Saena, S. yanto, A. Amirah, J Pendidikan Teknologi Pertanian 6, 1 (2020)

9. H. Arfiah, Muftucha, O. Caman, J Akuakultuur Indonesia 5 (2006)

10. M.I. Effendie, Metode Biologi Perikanan (Yayasan Dewi Sri, Bogor, 1979)

11. O.T. Tcheghebe, V.R.S. Tala, F.N. Tatong, G.K. Tchuente, Medicine and Medical Sciences (LRJMSS) 4, 2 (2017)

12. A.A. Makinde, J.O. Igoli, L. TA'Ama, S.J. Shaibu, A. Garba, African Journal of Biotechnology 6, 13 (2007)

13. R.P.S. Kumar, V. Malayaman, S. Shinduja, J of Chemical and Pharmaceutical Research 5, 11 (2013)

14. R. Dewi, Y. Firza, M. Nashiry, F.S. Al-Suede, A.S.A. Majid, Australian Herbal Insight 2 (2019)

15. J.M.N. Abille, A Review on The Medicinal Plant Cassia alata (L.) ROXB. (FABACEAE)

(Biological Sciences Department, College of Science \& Computer Studies De La Salle University - Dasmarinas, Cavite, Philippines pp 112, 2019)

16. Rosidah, W.M. Afizia J Akuatika 3, 1 (2012)

17. R.S. Hardhini, Amir, D.N. Setyowati J Perikanan 8, 1 (2018)

18. F.M. Nur, R.A. Nugroho, S. Fachmy. AIP Conference Proceedings 1813, (2017)

19. R.A. Nugroho, R. Aryani, W.D. Anggraini, E.H. Hardi, R. Rudianto, E. Kusumawati, S. Sudrajat, F.M. Nur, H. Manurung. IOP Conference Series: Earth and Environmental Science 348, 1(2019)

20. A. Happy, M.Soumya, S.V. Kumar, S. Rajeshkumar, R.D. Sheba, T. Lakshmi, V.D. Nallaswamy, Biochemistry and Biophysics Reports 17 (2019)

21. S.A. Gaddam, V.S. Kotakadi, D.V.R.S. Gopal, Y.S. Rao, A.V. Reddy, J of Nanostructure Chemistry 4 (2014)

22. A.T. Bowo, Sunarto, Rachimi, J Ruaya 1, 1 (2014)

23. Standar Nasional Indonesia,Produksi Benih Ikan Patin Siam (Pangasius hyphthalamus) Kelas Benih Sebar (SNI : 01- 6483.4 - 2000)

24. P.L. Putra, D. Jubaedah, M. Syaifudin, $J$ Akuakultur Rawa Indonesia 8, 1 (2020) 